\title{
THE CHALLENGE OF PROMOTING
} ETHNIC MINORITY EDUCATION AND CULTURAL DIVERSITY IN HONG KONG SCHOOLS: FROM POLICY TO PRACTICE

\author{
El desafío de promover la educación de los grupos \\ étnicos minoritarios y la diversidad cultural en las \\ escuelas de Hong Kong: de las políticas a la práctica
}

Ming-tak Hue \& Kerry J. Kennedy *

\section{$\underline{\text { ABSTRACT }}$}

An important feature of Hong Kong's education reform over the past decade has been the articulation of the "no loser principle". This policy statement was meant to signal that all students are valuable and will benefit from both basic and senior secondary education. Yet barriers remain for the $2.9 \%$ of students under the age of 15 who can be classified as ethnic minorities. Until the 2008 Racial Discrimination Ordinance (RDO), the educational needs of these students remained an invisible issue for the school system. This article examines the policy context in which Hong Kong schools have made provisions for ethnic minority students, and reviews classroom practices that operationalize these policies on a daily basis. In an interview study involving 32 teachers' narratives of how they managed the cultural diversity of ethnic minority students in classrooms (Hue \& Kennedy,

\footnotetext{
* The Hong Kong Institute of Education (China).
} 
2012, 2013), it was reported that at the practical level, teachers struggle to meet the diverse needs of students and to conceptualize a new rationale for responding to cultural diversity. The implications of promoting ethnic minority education at the three levels of policy, practice and research are discussed.

KEY WORDS: Anti-discrimination; Cultural diversity; Ethnic minority.

\section{RESUMEN}

Un rasgo importante de las reformas educativas puesta en marcha en Hong Kong a lo largo de la última década ha sido el "principio del no perdedor". Esta afirmación política estaba orientada a señalar que todos los alumnos son importantes y se beneficiarán de una educación básica y secundaria. Sin embargo, se mantiene una barrera para el 2,9\% de alumnos menores de 15 años clasificados como pertenecientes a alguna minoría étnica. Hasta la Orden de Discriminación Racial (Racial Discrimination Ordinance, RDO) de 2008, las necesidades educativas de estos alumnos permanecían ocultas para el sistema educativo. Este artículo examina el contexto político en el que las escuelas de Hong Kong han aprobado medidas especiales para los alumnos de minorías étnicas, y revisa las prácticas de aula que a diario hacen operativas estas políticas. A través de un estudio de entrevistas que recogen los testimonios de 32 profesores sobre cómo abordan la diversidad cultural que representan los alumnos pertenecientes a minorías étnicas (Hue y Kennedy, 2012, 2013), se pude establecer que al nivel de la práctica, los profesores luchan por responder a las diversas necesidades de sus alumnos y encontrar los medios para atender a la diversidad cultural. Se discuten las implicaciones que tiene promover la educación de las minorías étnicas en los tres niveles: político, práctico e investigador.

PALABRAS CLAVE: No discriminación; Diversidad cultural; Minorías étnicas.

$$
* * * * *
$$

\section{INTRODUCTION}

Hong Kong is conventionally recognized as an international city and one of the key financial center in the world. However, this recognition does not necessarily imply that the city itself is multicultural. A basically monocultural situation can be seen in the composition of Hong Kong's population. Some $95 \%$ of the people are Chinese, leaving just a small segment made up of other groups. When this 5\% is broken down, the majority are Filipinas, who work in Hong Kong largely as domestic helpers (32.9\% of the non-Chinese population, or around 112,583 people). The next-largest minority are Indonesians $(25.7 \%$, or about 87,945 people). The third largest group is made up of South Asian people (Indian, 
Pakistani and Nepalese) who together make up $13.9 \%$ of the non-Chinese population, or around 47,566 people. Westerners make up an even smaller group $(10.6 \%$, or about 36,273$)$ (CENSUS AND STATISTICS DEPARTMENT, 2007, p. 5). Due to the low percentage of non-Chinese people, ethnic minority groups are almost invisible. In addition, because of the geographic dispersion of these groups, it is entirely possible for them to live in Hong Kong without being aware of its ethnic diversity.

The small segment of ethnic minorities is consistently reflected in Hong Kong's school population. The vast majority of Hong Kong's students are Chinese, and only 1.94\% of its school population is classified as being made up by ethnic minorities (School Education Statistics Section, Education Bureau [SESS, EDB], 2012). From the most recent figures provided by the Education Bureau in 2011/12, 14,076 students at primary and secondary schools in the public sector come ethnic groups such as Indian, Indonesian, Nepalese, Pakistani, Filipino and Thai (SESS, EDB, 2012). The number of these students has been growing as a result of continuous immigration to Hong Kong. In 2001, 11,204 ethnic minority students under the age of 15 years were enrolled in Hong Kong schools. By 2006 , the number had grown by $20 \%$ to 13,472 , and in 2007 there were 28,722 ethnic minority students studying full time at educational institutions in Hong Kong (CENSUS AND STATISTICS DEPARTMENT, 2007). Between 2007 and 2012, the number of nonChinese-speaking or ethnic minority students in secondary schools increased by $94.77 \%$, from 3,272 to 6,373 (SESS, EDB, 2012).

Despite the increase in numbers at primary and secondary levels, the enrolment rate of this student group into local universities has remained consistently low compared with that of local Chinese students. The low enrolment rate could be explained by the fact that the majority of these students are among the lowest achievers academically. They commonly come from poor socioeconomic backgrounds, and they often experience difficulty in learning Chinese and English. Some researchers have thus raised concerns about the school support provided for the academic success of these students (BHOWMIK, 2013; BHOWMIK \& KENNEDY, 2013; KENNEDY, 2011, 2012). Similarly, many NGOs and advocacy groups have questioned the appropriateness of the support measures provided for ethnic minority students.

To explore the challenge of promoting ethnic minority education, this article examines the relevant policy context for the provision of education to these minorities, and explores the existing support measures for ethnic minority students at the school level. It then shifts to the practical level by reporting some findings from the authors' interview study of teachers' narratives on managing cultural diversity in the classroom (HUE \& KENNEDY, 2012, 2013). 


\section{POLICY CONTEXT}

In Hong Kong, no specific policy has been formulated for the promotion of ethnic minority or multicultural education, even though the government offers some measures to support ethnic minority students in adapting to Hong Kong schools. This article identifies two policies as primary determinants of the context in which ethnic minority education is articulated. The first and most influential policy is the Race Discrimination Ordinance (RDO). The Race Discrimination Bill () was formulated as a consultation paper in 2004 (HOME AFFAIRS BUAREAU, 2004), and eventually passed into law as the Race Discrimination Ordinance in 2008. The other policy is the principle of "no losers" in the classroom, which was advocated and implemented under the education reform in 2000 (KENNEDY, 2012). The relevance of these two policies to the context and provision of ethnic minority education is further explained below.

\section{$\underline{\text { 1.1. Policy on anti-discrimination }}$}

In Hong Kong, the policy of support for ethnic minority students has been made very political and less educational since the consultation of the RDB was conducted in 2000. Most of the time, the participants deeply involved in discussion and debate over this policy have been either politicians or advocacy groups for the rights of ethnic minorities. Their main concern has been how the anti-discrimination principle can be successfully applied in the context of education, especially in terms of equal access for ethnic minority students. In the mass media and the press, NGOs have strongly pressed the government to uphold the principle of ethnic minority education, and to proactively safeguard the rights and welfare of minorities. Comparatively, school practitioners of both the majority and minority ethnic groups have been mainly silent, and rarely involved in this kind of discussion or debate. As a result, the teachers' struggles, experiences and concerns about ethnic minority education have not been effectively explored or made known to the public.

The low level of teachers' participation in this debate can be explained by the way that school participants try to make sense of ethnic minority students' diverse learning needs. The teachers are generally concerned with teaching strategies rather than legal requirements concerning anti-discrimination or the rights of ethnic minority people in Hong Kong. For example, as the findings of the authors' interview study show (HUE \& KENNEDY, 2012, 2013), most teachers believe that their schools have put a serious effort into developing various strategies for supporting ethnic minority students. The teachers feel they have operated with an ethos of fairness and cultural harmony toward creating a discrimination-free environment. They insist that their schools were already committed to these goals long before the consultation on the RDB and the enforcement of the resulting ordinance. The teachers also feel that whatever efforts they have made in teaching minority students have been done entirely for the welfare of those students. Most teachers consider 
the race discrimination policy as a political act that could certainly cause some legal changes. However, they doubt that it can lead to any real and positive change in the learning of ethnic minority students or the everyday operation of the classroom. They hence tend to avoid getting involved in legal issues, and prefer to let the politicians do their jobs.

In fact, the enforcement of the RDO has been widely criticised as problematic. For example, many NGOs engaged in advocacy for the rights of ethnic minority groups have complained that the ordinance is difficult to enforce, especially in relation to how current issues of the provision for ethnic minority students in Hong Kong's schools can be recognised and addressed. At least two problems are repeatedly identified: the lack of mandatory requirements for schools to make changes in accommodating ethnic minority students, and the exclusion of language issues. Under the ordinance, no educational establishment is allowed to discriminate against any person on the grounds of race. However, the main focus of its legal concern is the terms of admission and access to services. This means that it could be against the law if any school refuses to offer placement for ethnic minority students who are of the legal age for schooling. As the ordinance states,

“(1) It is unlawful for the responsible body for an educational establishment to discriminate against a person-

(a) in the terms on which it offers to admit that person to the establishment as a student;

(b) by refusing, or deliberately omitting to accept, an application for that person's admission to the establishment as a student; or

(c) where the person is a student of the establishment-

(i) in the way it affords the person access to any benefits, facilities or services, or by refusing or deliberately omitting to afford the person access to them; or

(ii) by expelling the person from the establishment or subjecting him or her to any other detriment" (RDO, 2008, Clause 26(1)).

However, it is not mandatory for schools to make any changes or special arrangements for people of any race. As the ordinance states,

"(2) Nothing in subsection (1) is to be construed as requiring the responsible body for an educational establishment-

(a) to modify for persons of any racial group arrangements of the establishment regarding holidays or medium of instruction; or

(b) to make different arrangements regarding holidays or medium of instruction for persons of any racial group" (RDO, 2008, Clause 26(2)).

In addition, the ordinance does not specify whether the use or failure to use a particular language could lead to discrimination. While this important issue has not been clarified, based upon the principle of Clause 26(2), it can be assumed that Hong Kong schools are not required to make any modifications to the language of instruction or take into consideration the language needs of ethnic minority students in the course of their instruction. At its most extreme, this policy has meant that although schools cannot 
discriminate against ethnic minority students in terms of admission, the schools are not required to do anything to support the students' particular learning needs once they enter the school.

There are also problems of enforcement. The RDO has been criticized as lacking specific requirements on how multicultural elements are to be accommodated beyond stating that discrimination is illegal (KENNEDY, 2011, 2012). The government has entered a challenging context in which it intends to address cultural diversity issues by legislating against discrimination. Although the RDO informs schools in general of what discriminatory acts they must not do, the law says very little about what schools should do to actually promote multiculturalism and improve the management of cultural diversity. The law does not state what schools should do to proactively create a discrimination-free environment in schools. Joppke (2004) argues that the opposite side of "antidiscrimination" is "multiculturalism". "Anti-discrimination" refers to what should not be done, whereas "multiculturalism" refers to what should be done. Both elements should be addressed and managed simultaneously, to ensure that the issues of cultural diversity can be properly dealt with. If we take Joppke's perspective to examine the case of Hong Kong schools, it can be seen that the promotion of anti-discrimination is presented as the sole means for recognizing cultural diversity. This principle, however, has not been situated within a broader framework of policy or context that acknowledges the value of cultural diversity within the society.

In examining the experience of Western societies, it can be seen that the Western concepts of multiculturalism are built upon various social theories of social justice and liberal democracy. Under this broader theoretical framework and set of values, the issues of discrimination are dealt with as multiculturalism is promoted. For example, Bokhorst-Heng (2007, p. 631) has identified "statal multicultural narratives" as the ideologies and political constructs that nation states use to justify and rationalize their understandings of multiculturalism. Her study into the specific narratives applied in Singapore and Canada shows that multiculturalism accommodates different jurisdictions when being examined within the contexts of various societies and political ideologies. In the case of Hong Kong, what is apparently missing in the discussion of anti-discrimination and cultural diversity is such a "statal multicultural narrative", that is, a broader theoretical framework and context for supporting diversity and acknowledging the value of such diversity. With the omission of such a narrative, anti-discrimination is seemingly pursued as a pragmatic policy objective, to be applied only in the ways deemed reasonable by the bureaucracy and the government, rather than as a social programmer for actually addressing the issues of cultural diversity. 


\subsection{Policy on the creation of "no loser" classrooms}

In addition to the policy on anti-discrimination, another relevant policy context in which ethnic minority education has been articulated is the application of the "no loser" principle for the support of all students' learning. This policy was introduced by Hong Kong's most recent education reform (EDUCATION COMMISSION [EC], 2000). The "no loser" principle reflects the educational aim to promote student-centered learning and cater to the diverse learning needs of individual students. As it is stated,

\footnotetext{
"There should not be, at any stage of education, dead-end screening that blocks further learning opportunities ... Teaching without any discrimination has been a cherished concept since ancient times. We should not give up on any single student, but rather let all students have the chance to develop their potentials. The aim of the education reform is to remove the obstacles in our system that obstruct learning, to give more room to students to show their initiative and to develop their potential in various domains" (EC, 2000, p. 9).
}

As schools confront the growing number of ethnic minority students, a related issue is that a rising proportion of these young people may be "out of school" (BHOWMIK, 2013). Teachers are therefore growing increasingly concerned about what the "no loser" principle means for ethnic minority students, how it can be implemented to promote student-centred learning, and how it can ensure that every student benefits from learning and assessment (KENNEDY, 2005, 2012). However, for those schools where ethnic minority students are accommodated, little research is available to inform teachers of the implementation of the "no loser" principle. It remains unclear how teaching and learning might be better focused to promote learning for ethnic minority students, and how relevant practices can be adopted for this purpose (HUE \& KENNEDY, 2012, 2013). Moreover, little attention has been paid to non-Chinese students in the unique cultural and educational context of Hong Kong society. Such local contexts have been shown to be important when it comes to school participants' conceptions of the "no loser" classroom (BROWN, KENNEDY, FOK, CHAN \& YU, 2009; BROWN, HUI, YU \& KENNEDY, 2011). Awareness of cultural influence can inform teachers and curriculum leaders concerning how the practices of teaching and learning, as borrowed from Western societies, can be better adapted to fit the cultural contexts of non-Western societies.

\section{VARIOUS SUPPORT MEASURES}

Both before and after the formal enactment of the RDO and the "no loser" principle, the government's Education and Manpower Bureau (now the Education Bureau, or EDB) sought to address a range of issues affecting ethnic minority students. Accordingly, the EDB put through several measures to support the learning of ethnic minority students at the school level. These measures include an initiation program, a new admission scheme, an induction program, and a program for teaching Chinese to non-Chinese-speaking students. It is necessary to point out that these measures are piecemeal and have not been applied 
within any overarching theoretical framework or context. Each of these measures tends to operate without any connection with the others. The various EDB programs are briefly described below.

\section{$\underline{\text { 2.1. Initiation program }}$}

Since 2000, the EDB has launched a six-month full-time initiation program for newly arrived children. The program is run as a support service for this group of students before they enroll into mainstream schools in Hong Kong. As an integrated program, the initiation effort aims to improve the children's Chinese and English language abilities, to assist them in adapting to the school environment in Hong Kong, and to facilitate their whole person growth and social adaptation. The program is operated in a school setting, and each school enjoys the autonomy of using the program funds and resources to design its own curriculum to meet the students' needs (EDUCATION AND MANPOWER BUREAU, 2004b).

\subsection{New admissions scheme}

Before the 2004-2005 school year, ethnic minority children suffered from a limited choice of schools. There were only four public sector schools (two primary and two secondary schools) providing non-Chinese curriculum (KU et al., 2005). To enhance the number of schools that could accommodate this group of students, more schools were specially designated to offer ethnic minority education. In 2013, however, the designation system was abolished, due to its violation of the Race Discrimination Ordinance. By then there were in total 30 designated schools in Hong Kong. Under the current school placement policy, children of ethnic minority families can approach schools by themselves, as long as the schools can provide support for learning Chinese. According to the ordinance, schools have no right to deny placement to students due to their racial background if they meet all of the basic requirements of school enrolment.

\section{$\underline{\text { 2.3. Induction program }}$}

Since 2005, a 60-hour induction program has been offered for newly arrived children, including both Chinese and non-Chinese-speaking students. This program aims to promote children's personal development, social adaptation and basic learning skills, and to help them adapt to their new social and schooling environment. The program is now operated by non-government organizations (EDUCATION AND MANPOWER BUREAU, 2004a). 


\subsection{Teaching Chinese to non-Chinese-speaking students}

The teaching of Chinese to students whose first language is not Chinese has emerged as a significant issue following the introduction of the RDB into the Legislative Council. Ethnic minority groups have wanted an alternative Chinese curriculum for nonChinese-speaking students. The EDB has insisted that the standard Chinese curriculum, with suitable school-based adaptations, should be appropriate. It took a resolution of the Legislative Council to force the issue, which in 2007 ruled as follows:

\footnotetext{
"That this Panel urges the Government to immediately formulate an alternative Chinese Language curriculum for non-Chinese-speaking students, and establish another open examination which is recognised by local universities as a channel for non-Chinese-speaking students to enter universities and receive post-secondary education in Hong Kong” (LEGISLATIVE COUNCIL, 2007, p. 5)
}

Some twelve months later, the EDB released its "alternative curriculum" for consultation. However, it was not an alternative curriculum but a "Supplementary guide to the Chinese language curriculum for non-Chinese-speaking (NCS) students" (Education Bureau, 2008). The guide proposed a range of teaching strategies and organizational arrangements for teaching Chinese, but it did not set out a new curriculum for second language learners.

All in all, the aforementioned support measures offered by the EDB have not had any specified structural connection with any currently implemented educational policies. Neither are these measures designed to promote any educational elements of multiculturalism or cultural diversity. However, it is clear that the measures are designed to improve learning opportunities for ethnic minority students, while ensuring that the government cannot be accused of any form of discrimination. The avoidance of discrimination is a particularly high priority since the enactment of the Race Discrimination Ordinance in 2008. Even so, community advocates have constantly challenged the EDB's support measures, and have sought to further improve the provision of assistance to ethnic minority students. It is of interest to note that ethnic community advocacy groups have used an avowedly political process in their efforts to secure the welfare of ethnic minority students. They have done so focusing mainly on the legal perspective of antidiscrimination, rather than the educational perspective of teaching, learning and enabling cultural diversity.

\section{TEACHERS' CLASSROOM EXPERIENCE}

Having examined the policy context for ethnic minority education in Hong Kong, and briefly described the support measures for ethnic minority students, it is time to examine the actual situation of ethnic minority students in the classroom. This section discusses some of the findings from the authors' study (HUE \& KENNEDY, 2012, 2013) 
in which 32 secondary school teachers shared their narratives and observations concerning their management of cultural diversity in the classroom. The focus is on the teachers' understandings of multiculturalism and their views on developing a rationale for addressing the issues of cultural diversity.

\subsection{Managing cultural diversity in the classroom}

When talking about multiculturalism, the teachers tried to make sense of the concept by reference to the division between the local and the non-local, in terms of people, cultures, religions and ways of living. In using of this "division", they classified four categories of students: Hong Kong Chinese students, ethnic minority students (EMS) born in Hong Kong, new immigrant EMS, and new immigrant students from mainland China. The first category was considered "the local", whereas the others were "the non-local". When these various categories of students were put into the classroom, the chemistry of the different combinations of students brought a number of unique characteristics to the schools and the classrooms involved. For example, from the perspective of managing cultural diversity, multiculturalism was mainly about how the different learning styles of these groups of students could be managed. Most of the teachers tended to be more confident in classrooms with a single category of students. The teachers normally felt it was a challenge for them to teach in a mixed classroom. As they explained, Hong Kong Chinese students preferred more "sit and listen" or "chalk and talk" approaches to teaching and learning. Ethnic minority students were keener on engaging in learning activities. They responded quickly to the teachers' requests in the classroom, and raised hands when the teachers posed questions. Hong Kong Chinese students tended to be more "inactive" and more "slowly-heated" (or unmotivated). Ethnic minority students, however, had relatively short concentration spans. They disliked the "chalk and talk" teaching approach, which they usually found boring. Understanding this, teachers tended to adopt a kind of "yin-andyang" approach to teaching by interchanging various forms of teacher-centered and student-centered strategies. The "yang" side of the approach referred to greater dominance of the teacher's role in the process of learning, and this approach was directed to the local Chinese students. The "yin" side referred to activities involving less dominance of the teacher's role, and this approach was aimed at ethnic minority students.

Furthermore, in the view of the teachers, multiculturalism was mainly about language. They felt that language was the most prominent type of diversity among the students that needed to be fully addressed, especially for the two categories of immigrant students. Because of the wide range of students' abilities in English and Chinese, as highlighted by the narratives of both teachers and students, the policy of streaming was adopted, in which students were streamed into different classes according to their language abilities. The three types of classes were "Chinese classes", "ethnic minority classes" and "mixed classes". Basically, students who could be taught in Chinese were streamed into 
"Chinese classes", which generally included the local Hong Kong students and the new immigrants from mainland China. Students who could not speak and read Chinese, such as the new immigrant EMS or EMS born in Hong Kong, were streamed into either "ethnic minority classes" or "mixed classes". Some Chinese students who had an ability to learn in English were placed in "mixed classes" to learn with the ethnic minority students. Similarly, some EMS who had an ability to speak and write Chinese could be put into "Chinese classes", but this happened quite rarely, as most of the EMS could only speak Cantonese (the dialect of Chinese commonly used in Hong Kong), and they were usually unable to write Chinese.

The teachers found that this streaming policy was "not perfect", but at least it was "a relatively good strategy" for their schools to adopt for creating a multicultural environment in which the students' diverse learning needs could be better fulfilled. The teachers also described their streaming approach as "the no-other-alternative way", "the only-one way" or "the relatively good way" to manage the diverse learning needs of students, especially in schools where the percentages of Chinese students and ethnic minority students were almost the same.

Although the teachers emphasized the positive aspects of the streaming policy, one of this policy's prominent side effects was segregation between Chinese students and ethnic minority students. This phenomenon drew teachers' concerns about the effects of streaming on the promotion of "cultural harmony" or "cultural integration". As the teachers observed, in both the Chinese and ethnic minority classes, the Chinese and the ethnic minority students had no opportunity to interact with each other, except when brought together in other school contexts beyond the classroom. In mixed classes, segregation could also be seen. Even though the Chinese and ethnic minority students were both in the same class, the interaction between these groups tended to be limited. They seemed to interact only when requested by their teachers to engage in collaborative learning activities. Most of the time, Chinese students stayed together and ethnic minority students did the same.

\subsection{Promoting multiculturalism within the classroom and beyond}

When the teachers attempted to manage cultural diversity, they did not think it was enough to merely promote multiculturalism within the school. They felt that ethnic minority students should be enabled to integrate into Hong Kong society. This goal was considered as the paramount aim for ethnic minority education, and the teachers realized that it was a great challenge for them. As one teacher put it,

"Inside the walls of the school, we all put great effort in making all students included and integrated, regardless of the origin of their countries and where they are from. But the world beyond the walls of the school is still totally different from what happens within the school. Despite this, we keep doing it anyway!" 
To better manage cultural diversity, the teachers intended to minimise the differences between students by insisting that all students are equal, and that all cultural differences, such as various traditional customs and religious festivals, should be appreciated. This attitude was reflected by the teachers' narratives of "multiculturalism" that they intended to create in the classroom and beyond. These narratives were also linked to another ethos, that of promoting of "cultural integration" and "cultural harmony". This ethos could be defined as a school environment in which school practitioners respected each other regardless of race, religion or culture, and valued diversity as a strength of classroom learning and of the school community. This ethos also appeared in the way the teachers disagreed with the government's static definition of ethnic minority students as "non-Chinese students". The teachers felt that this term reflected the domination of the host society's culture, and neglected the cultural diversity of ethnic minority students. When invited to interpret these constructs in depth, some teachers apparently felt puzzled by the adoption of the dominant local culture for acculturation, and they questioned the type of culture into which ethnic minority students had to be integrated. As two teachers put it,

\begin{abstract}
"Is there a culture called non-Chinese? How do they behave? Where is non-China? If you are ethnically Chinese but live in South Africa, what is your culture? We have Chinese students like this. What about ethnic Pakistanis that behave like Chinese? Focus on the individual and less on the group. I have seen Filipinos behave like Chinese and Chinese behave like Pakistanis".

"We don't see them (ethnic minority students) as non-Chinese students. It is very wrong to put ethnic minority students as a single category of students, compared to Chinese. If you looked at them (ethnic minority students) closely, you would understand that they are all so different. The differences are so vast, much more different than you imagine ... In my eyes, there is no distinction between Chinese students and non-Chinese students. Rather, I try to see them all individually. Race is only one of the differences between them".
\end{abstract}

\title{
3.3. Searching for a new meaning of multiculturalism
}

When examining the teachers' understandings of multiculturalism, it could be seen that the current ethos of "cultural harmony" led the schools to treat ethnic minority students similarly to the Chinese students, focusing on the similarities of the different racial groups rather than their differences. Teachers were worried that they would be accused of being unfair and unjust if they managed Chinese and ethnic minority students differently. When managing diversity in the classroom, the teachers therefore attempted to maintain fairness and sufficiency of instruction for both Chinese and ethnic minority students, and to keep relations harmonious between the majority and the minority classmates. As the common Chinese sayings suggest, "under the same principle of benevolence, all people should be treated equally" (一視同仁), and "people do not mind having nothing at all, but they do mind inequality” (不患貧而患不均). The principles of benevolence, sufficiency and equality underlying these sayings are rooted in Confucianism. Some teachers used these 
principles to describe how ethnic minority students were supported, and how their needs were fulfilled by the teachers adhering to a philosophy of equality. As two teachers put it,

"If I pay excessive attention to them (ethnic minority students), what the Chinese students say is, "the teacher is unfair"... We need to be fair. As the saying goes, "people do not mind having nothing at all, but they do mind inequality", this is what we are trying to do".

"We are trying to ensure that all students are treated equally, especially when they are disciplined. This is crucial in our school, because students come from different countries. They are very sensitive to how you manage things, and the issues of race come up quickly ... Therefore, we are trying to ensure that "under the same principle of benevolence, all people should be treated equally".

The teachers stressed that fulfilling the diverse learning needs of students could become a challenge for them when using the current ethos of "cultural harmony" to promote multiculturalism, as the Confucian doctrine of fairness, justice and equity is still deeply rooted in the dominant Hong Kong culture. They thus asserted the need for formulating "a new rationale of multiculturalism" and for developing a fresh model of "cultural harmony". They felt that both these rationales should inform the context of Hong Kong schools. As one teacher said,

"It is impossible for their (ethnic minority) culture to be taken away, especially when we teach in the classroom. It is a must to keep their culture, and not emphasise the "mainstream" culture (Chinese). [We should] show respect for it (the culture of ethnic minority people). During integration, their particular characteristics should be preserved ... so that they are provided with a sense of security ... We certainly need to have a new rationale, a new way and a new model for cultural integration. How do I say it ... the current one is too Chinese; the new one should be built upon a broader set of cultural values".

\section{CONCLUSION}

This article intends to examine the policy context of ethnic minority education in Hong Kong, with a focus on how ethnic minorities has been supported in learning and how their cultural diversity has been accommodated at the practical level. The enforcement of the Race Discrimination Ordinance and the principle of the "no loser" classroom have served to frame the key policy context for the provision of ethnic minority education. However, these policies, especially the policy on anti-discrimination, constitute a political platform rather than an educational one, wherein ethnic minority groups have pursued their advocacy for greater support for ethnic minority students. This development suggests why the discussion on issues of the ethnic minority education is becoming more politicized, and less educational.

Although no mention of specific multicultural elements or any "statal multicultural narrative" are present in the Race Discrimination Ordinance or the existing support measures, there is a growing drive to locate the anti-discrimination and the multiculturalism initiatives in broader social, educational and theoretical contexts, as this article has pointed 
out. This drive is reflected in the way that teachers who work closely with ethnic minority students are constantly searching for a new rationale to make sense of multiculturalism. These teachers are questioning the existing policies on ethnic minority education and broadening the relevant practice for accommodation of cultural diversity. To build up such a broader theoretical framework and a policy based upon the uniqueness of Hong Kong's situation, a more collaborative and less political platform for cooperation (rather than criticism) should be created. Such a platform can better enable the various parties of the EDB, ethnic minority groups and school practitioners to develop a common ground of commitment to social justice, the academic success of ethnic minority students, and their integration into the local society.

The growing drive for a new rationale, narrative and platform for ethnic minority education converge in an important message. The Western concepts of social justice and multiculturalism are not the same as those that underlie Confucian societies such as Hong Kong (CHIU \& HONG, 1997; CHAN, 2001, 2005). Under the cultural influence of Confucianism in Hong Kong's context, the rationale of social justice can be more accurately unfolded under the concept of social harmony, in which individuals are culturally encouraged to prepare themselves for giving up some personal freedoms for the sake of achieving higher goals of collective accomplishment. Such collective goals aim at creating a stable and harmonious society, in which the individual contribution is compensated and brings a greater community-wide benefit. Furthermore, it has been argued that the principle of "sufficiency for all" enables the creation and maintenance of social harmony. As Chan (2001) suggests, "when it comes to matters about people's well-being, material welfare and life chances, Confucian justice seeks to promote sufficiency for all and not equality between individuals". This concept of social justice is expressed through the idea of impartiality, as a cornerstone for social harmony. As Chan (2001) explains further,

\footnotetext{
"Political rule should be impartial or fair (gong in Chinese) to everyone. By that it means political rule should promote the good of everyone without prejudice or favouritism. In other words, it would be a violation of fairness or justice (gong) if the ruler were selectively concerned about some people only".
}

This concept of impartiality and social harmony can explain the insistence of government policies on a common curriculum, a common examination, limited support measures, and a reluctance to expand the provision of ethnic minority education. If the analysis given in this article proves to be correct, it can be inferred that the principle being used by the EDB can be described as sufficient provision rather than equitable provision. This means that the commitment is not to equal outcomes, as is often the case in many Western countries, but to a level of provision judged to bring educational services for ethnic minority students into line with the kinds of services that are provided for all other students. This analysis further confirms the research findings that each society has to create the meaning of multiculturalism and diversity within the context of its own society, cultural 
values and political ideologies (BOKHORST-HENG, 2007). Rather than constantly "importing" concepts and values from other societies, each society needs to construct narratives that will be well-suited to the benefit of its unique societal, cultural and political situation.

Empirically, there are many issues and concerns that should be further explored and addressed, so that the various parties of the EDB, NGOs and school practitioners can be better informed of effective ways for promoting ethnic minority education, both at the policy and the practical levels. In doing this, Ayers $(2004,2006)$ calls for a strong social justice agenda for educational research in which both researchers and practitioners should critically question current practices, and confront the orthodoxy of existing policies (AYERS, 2006). Ayers believes that the core of such inquiry "must be human knowledge and human freedom, both enlightenment and emancipation" (AYERS, 2006: 87). In achieving this goal, the following questions can be posed for this form of inquiry:

"1. What are the issues that marginalised or disadvantaged people speak of with excitement, anger, fear or hope?

2. How can I enter a dialogue in which I will learn from a specific community about the problems and obstacles its members face?

3. What endogenous experiences do people already have that can point the way toward solutions?

4. What is missing from the "official story" that will make the problems of the oppressed more understandable?

5. What current proposed policies serve the privileged and the powerful, and how are these policies made to appear inevitable?

6. How can the public space for discussion, problem posing, and problem solving be expanded?" (AYERS, 2006, p. 88).

Commitment and advocacy for the welfare of ethnic minority students can only be cultivated successfully through collaboration between policy-makers, practitioners and researchers. These participants in this process should share their concerns to work together as allies with schools and communities, to take the concerns of individual ethnic minority students to heart, and to develop strategies that enact educational change at both the policy and practical levels. The strategies they create need to foster social justice, multiculturalism, cultural diversity and anti-discrimination. For us, this expanded provision of ethnic minority education and of collaboration embodies new possibilities and creates new hopes. By working in a more collaborative way, we hope to invent spaces where we can develop the diversity of human capacities more fully in an increasingly changing and diversifying society.

\section{ACKNOWLEDGMENTS}

This research was funded with General Research Grant (GRF-HKIEd842613) from Hong Kong's Research Grants Council, between 2013 and 2016. 


\section{BIBLIOGRAPHIC REFERENCES}

AYERS, W. C. (2004): Teaching toward freedom: Moral commitment and ethical action in the classroom (Boston: Beacon Press).

AYERS, W. C. (2006): Trudge toward freedom: Educational research in the public interest, in G. LADSON-BILLINGS and W. F. TATE (Eds.), Education research in the public interest: Social justice, action and policy, pp. 81-97 (New York: Teachers College Press).

BHOWMILK, M. K. and KENNEDY, K. J. (2013): Equitable educational provision for Hong Kong's ethnic minority students: Issues and priorities (New Horizons in Education, in press).

BOKSHORST-HENG, W. D. (2007): Multiculturalism's narratives in Singapore and Canada: Exploring a model for comparative multiculturalism and multicultural education. Journal of Curriculum Studies, 39 (6), pp. 629-658.

BROWN, G., HUI, S. F. K., YU, W. M. and KENNEDY K. (2011): Teachers' conceptions of assessment in Chinese contexts: A tripartite model of accountability, improvement and relevance. International Journal of Educational Research, 50 (56), pp. 307-320.

BROWN, G., KENNEDY, K., FOK, P. K., CHAN, J. K. S. and YU, W. M. (2009): Assessment for student improvement: Understanding Hong Kong teachers' conceptions and practices of assessment. Assessment in Education: Principles, Policy and Practice, 16 (3), pp. 361-377.

CENSUS AND STATISTICS DEPARTMENT. (2007): 2006 population by-census. Thematic report: Ethnic minorities (Hong Kong).

CHAN, P. (2005): Hong Kong's proposed race anti-discrimination legislation: A discriminatory bill excluding mainland Chinese immigrants from protection. Chinese Journal of International Law, 4 (2), pp. 599-605.

CHUI, C. and HONG, Y. (1997): Justice in Chinese societies, in H. KAO and D. SINHA (Eds.), Asian perspectives on psychology, pp. 165-184 (Thousand Oaks, CA, Sage Publications).

HUE, M. T. and KENNEDY, K. J. (2012): Creation of culturally responsive classrooms: Teachers' conceptualisation of a new rationale for cultural responsiveness and management of diversity in Hong Kong secondary schools. Intercultural Education, 23 (2), pp. 119-132. doi: 10.1080/14675986.2012.686021.

HUE, M. T. and KENNEDY, K. J. (2013): Building a connected classroom: Teachers' narratives about managing the cultural diversity of ethnic minority students in Hong Kong secondary schools (Pastoral Care in Education, in press).

JOPPKE, C. (2004): Ethnic diversity and the state. The British Journal of Sociology, 55 (3), pp. 451-463.

KENNEDY, K. (2005): Changing schools for changing times: New directions for the school curriculum in Hong Kong (Hong Kong, The Chinese University Press). 
KENNEDY, K. (2011): The "long march" to multiculturalism: Policymaking in Hong Kong to support ethnic minority students. In J. PHILLION, M. T. HUE and Y. WANG (Eds.), Education for Minority Students in East Asia: Government Policies, School Practices and Teacher Responses, pp. 155-173 (New York: Routledge Series on Schools and Schooling in Asia).

KENNEDY, K. (2012): The "No Loser" principle in Hong Kong's education reform: Does it apply to ethnic minority students? Hong Kong Teachers' Centre Journal, 11, pp. $1-23$.

KU, H. B., CHAN, K. W. and SANDHU, K. K. (2005): A research report on the education of South Asian ethnic minority groups in Hong Kong (Hong Kong: Department of Applied Social Sciences, The Hong Kong Polytechnic University and Unison Hong Kong).

SCHOOL EDUCATION STATISTICS SECTION, EDUCATION BUREAU. (2012): Statistics on the non-Chinese speaking students (NCS) population between 2006 and 2011 (Hong Kong: Unpublished report by the Education Bureau, Hong Kong Special Administrative Region Government).

\section{ELECTRONIC REFERENCES}

BHOWMILK, M. K. (2013): Looking outside the school: "Out of school" ethnic minority children in Hong Kong. Comparative Education Bulletin, 15, pp. 34-46. (http://www.fe.hku.hk/cerc/ceshk/doc/CEB2013_15.pdf), consulted on 1 September 2013.

CHAN, J. (2001): Making sense of Confucian justice. Polylog: Forum for Intercultural Psychology, 3, (http://them.polylog.org/3/fjc-en.htm), consulted on 17 February 2008.

EDUCATION BUREAU. (2008): Consultation paper on developing a "Supplementary guide to the Chinese language curriculum for non-Chinese-speaking students" (in Chinese).

(http://www.edb.gov.hk/FileManager/TC/Content_93/devt_of_sg to chi_lang_curr ncs.pdf), consulted on 14 February 2008.

EDUCATION COMMISSION. (2000): Review of education system reform proposal. (http://www.info.gov.hk/archive/consult/2000/Full-Eng.pdf), consulted on 8 October 2013.

EDUCATION AND MANPOWER BUREAU. (2004a): Full-time initiation programme for newly arrived children. In our services to students and parents: services. (http://www.emb.gov.hk, section on education and support services for newlyarrived children), consulted on 19 January 2006.

EDUCATION AND MANPOWER BUREAU. (2004b): Full time initiation programme school list. In our services to students and parents: services: education and support services for newly-arrived children. 
(http://www.emb.gov.hk/index.aspx?langno=1\&nodeID=3960), (consulted on 19 January 2006).

HOME AFFAIRS BUREAU. (2004): Legislating against racial discrimination - A consultation

paper. (http://www.hab.gov.hk/file_manager/en/documents/policy_responsibilities/public consultation/LARD.pdf), consulted on 20 February 2008.

RACE DISCRIMINATION ORDINANCE (2008)

(http://www.legislation.gov.hk/blis_pdf.nsf/6799165D2FEE3FA94825755E0033E5 32/7B5C41B095863F7C482575EF0020F30A? OpenDocument \&bt=0), consulted on 25 October 2013.

LEGISLATIVE COUNCIL. (2006): Hong Kong Christian Service to Chairman of Education Panel, 9 October 2006. Opinion on designated schools for non-Chinese speaking (NCS) students. (LC Paper No. CB(2)77/06-07(01). (http://www.legco.hk/yr06-07/english/panels/ed/papers/edcb2-77-1-e.pdf), consulted on 13 February 2008.

LEGISLATIVE COUNCIL. (2007): Background brief prepared by the Legislative Council Secretariat for the meeting on 8 January 2007. Provision of an alternative Chinese Language curriculum for non-Chinese speaking students. (LC Paper No. $\mathrm{CB}(2) 757 / 06-07(03))$.

(http://www.legco.hk/yr0607/english/panels/ed/papers/ed0108cb2-757-3-e.pdf), consulted on 14 February 2008.

\section{PROFESIOGRAFÍA}

\section{Ming-tak Hue}

Datos de contacto: Department of Special Education and Counselling, The Hong Kong Institute of Education. Telephone: +852 2948 7551. E-mail: mthue@,ied.edu.hk.

\section{Kerry John Kennedy}

Datos de contacto: Department of Curriculum and Instruction, The Hong Kong Institute of Education. Telephone: +852 2948 8525. E-mail: kerryk@ied.edu.hk.

Fecha de recepción: 5 de noviembre de 2013.

Fecha de revisión: 29 de diciembre de 2013 y 26 de febrero de 2014.

Fecha de aceptación: 4 de marzo de 2014. 